Elisa-Maria Hiemer, Jiří Holý, Agata Firlej, and Hana Nichtburgerová (Eds.)

Handbook of Polish, Czech, and Slovak Holocaust Fiction 



\section{Handbook of Polish, Czech, and Slovak Holocaust Fiction}

Works and Contexts

Edited by

Elisa-Maria Hiemer, Jiři Holý, Agata Firlej, and Hana Nichtburgerová 
In appreciation to the Conference on Jewish Material Claims Against Germany

(Claims Conference) for supporting this publication.

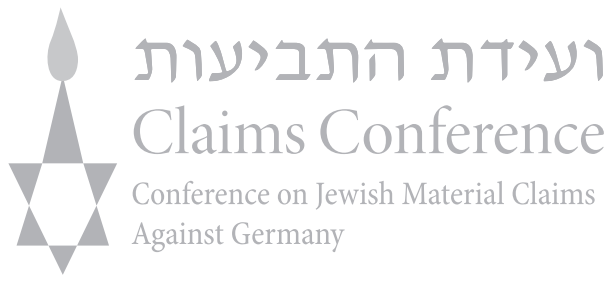

The publication was made possible thanks to the generous support of the Czech-German Future Fund.

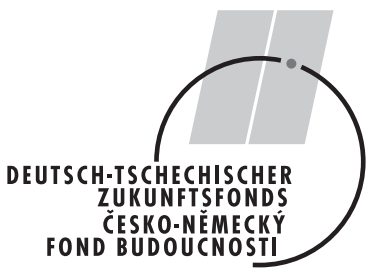

We are also grateful for the support by the Foundation for Holocaust Victims Prague, the Prague Centre for Jewish Studies, the Rector of the Adam Mickiewicz University Poznan and the Institute for Czech and Comparative Literature at Charles University, Q12 Literature and Performativity.

ISBN 978-3-11-066725-7

e-ISBN (PDF) 978-3-11-067105-6

e-ISBN (EPUB) 978-3-11-066741-7

DOI https://doi.org/10.1515/9783110671056

\section{(c) BY-NC-ND}

This work is licensed under the Creative Commons Attribution-NonCommercial-NoDerivatives 4.0 International License. To view a copy of this license, visit http://creativecommons.org/licenses/ by-nc-nd/4.0/.

\section{Library of Congress Control Number: 2020949262}

\section{Bibliographic information published by the Deutsche Nationalbibliothek}

The Deutsche Nationalbibliothek lists this publication in the Deutsche Nationalbibliografie; detailed bibliographic data are available on the Internet at http://dnb.dnb.de.

(C) 2021 Elisa-Maria Hiemer, Jiři Holý, Agata Firlej, and Hana Nichtburgerová, published by Walter de Gruyter GmbH, Berlin/Boston

The book is published open access at www.degruyter.com.

Cover image: by Jiří Sozanský from Mezní situace (2015).

Typesetting: jürgen ullrich typosatz, Nördlingen

Printing and binding: CPI books $\mathrm{GmbH}$, Leck

www.degruyter.com 